\title{
MAKNA SIMBOL ATAU MOTIF KAIN TENUN KHAS MASYARAKAT DAERAH BIMA DI KELURAHAN RABA DOMPU KOTA BIMA PROPINSI NUSA TENGGARA BARAT.
}

\author{
Ilmiawan Mubin \\ Pendidikan Sejarah, Universitas Muhammadiyah Mataram, ilmiawanbima@yahoo.co.id
}

INFO ARTIKEL
RiwayatArtikel:
Diterima: 05-11-2016
Disetujui: 04-12-2016

Kata Kunci:

1.Makna Simbol

2.Motif Kain Tenun

3. Khas Masyarakat Bima

\begin{abstract}
ABSTRAK
Abstrak:

Indonesia sebagai negara kepulauan, yang terdiri dari ribuan pulau yang membentang mulai Sabang hingga Merauke. Sebagai negara yang beribu-ribu pulau tentu memiliki potensi dan kekayaan alam untuk dikembangkan. Kita tahu berbagai potensi dan kekayaan alam banyak dijumpai diseluruh daerah di tanah air. Salah satu potensi dan kekayaan Nusantara terdapat di propinsi Nusa Tenggara Barat, tepatnya di Kota Bima yang memiliki sejarah dan leluhur yang mempunyai nilai eksotis untuk dapat dikembangkan, salah satunya yaitu Tenun Khas Bima.Budaya masyarakat Bima pada umumnya menjunjung tinggi adat istiadat dan tradisi serta modernisme di aktivitas formal, misalnya dalam acara hari ulang tahun lahirnya Kota Bima, dan acara lain yang bernuansa kelokalan. Atas dasar realita tersebut, keberadaan tenun daerah Bima di dalam acara tersebut sangatlah berperan sebagai pakaian formal kedaerahan dalam upacara adat dan tradisi Kota Bima.Keahlian membuat kain tenun khas Bima serta bentuk-bentuk motif dan makna nilai simbol yang merupakan warisan turun temurun yang hanya dimiliki oleh masyarakat daerah Bima, umumnya sebagai anak bangsa Indonesia, maka wajib mempertahankan keberadaan budaya tersebut serta ditumbuh kembangkan.
\end{abstract}

Indonesia as an archipelago, consisting of thousands of islands stretching from Sabang to Merauke. As a country with thousands of islands of course has the potential and natural wealth to be developed. We know the various potentials and natural wealth are found throughout many regions in the country. One of the potentials and riches of the archipelago is found in the province of West Nusa Tenggara, precisely in the city of Bima which has a history and ancestors that have exotic value to be developed, one of which is Typical Woven Bima.Budaya community culture generally uphold the customs and traditions and modernism in formal activities, for example in the birthday event of the birth of Kota Bima, and other events that have nuances of localization. On the basis of the reality, the existence of weaving Bima area in the event is very role as a regional formal clothing in traditional ceremonies and traditions of Bima City. Expertise to make woven cloth Bima typical and forms of motifs and symbols of meaning that is a hereditary heritage that is owned only by the Bima local community, generally as a child of the nation of Indonesia, it is mandatory to maintain the existence of the culture and grown to develop.

\section{A. LATAR BELAKANG}

Indonesia sebagai negara kepulauan, yang terdiri dari ribuan pulau yang membentang mulai Sabang hingga Merauke. Sebagai negara yang beribu-ribu pulau tentu memiliki potensi dan kekayaan alam untuk dikembangkan. Kita tahu berbagai potensi dan kekayaan alam banyak dijumpai diseluruh daerah di tanah air. Salah satu potensi dan kekayaan Nusantara terdapat di propinsi Nusa Tenggara Barat, tepatnya di Kota Bima yang memiliki sejarah dan leluhur yang mempunyai nilai eksotis untuk dapat dikembangkan, salah satunya yaitu Tenun Khas Bima.
Budaya masyarakat Bima pada umumnya menjunjung tinggi adat istiadat dan tradisi serta modernisme di aktivitas formal, misalnya dalam acara hari ulang tahun lahirnya Kota Bima, dan acara lain yang bernuansa kelokalan. Atas dasar realita tersebut, keberadaan tenun daerah Bima di dalam acara tersebut sangatlah berperan sebagai pakaian formal kedaerahan dalam upacara adat dan tradisi Kota Bima.

Keahlian membuat kain tenun khas Bima serta bentuk-bentuk motif dan makna nilai simbol yang merupakan warisan turun temurun yang hanya dimiliki oleh masyarakat daerah Bima, umumnya sebagai anak bangsa Indonesia, maka wajib mempertahankan 
keberadaan budaya tersebut serta ditumbuh kembangkan. Selain pewaris budaya tradisional, diharapkan bukan hanya sebagai pewaris yang pasif, namun turut serta melestarikan nilai-nilai tradisi budaya yang sudah ada. Salah satu kendala dalam melestarikan tenun Bima adalah Sumber Daya Manusia (SDM), kualitas kaum perempuan, ibu-ibu dan inisiatif para remaja untuk menenun yang sedikit demi sedikit berkurang seiring dengan perkembangan zaman. Hal tersebut dapat dilihat dikalangan remaja modern sangat berkurang yang berminat menjadi pengrajin. Sehingga, pengrajin tenun Bima berasal dari kalangan masyarakat biasa dan status sosial pendidikan rendah. Oleh karena itu, sebagai pengrajin dan pengelola diharapkan memiliki bakat dan minat sehingga sepadan dengan nilai-nilai semangat di zamannya (M. Hilir Ismail dan Malingi Alan, 2011: 17: 18).

Makna simbol kain Tenun khas daerah Bima Guna

mengembangkan dan meningkatkan kreatifitas dalam menciptakan nilai dan simbol jenis tenun Bima. Dari berbagai jenis bahan dengan mutu yang beraneka ragam, maka terdapat beraneka ragam kerajinan kain tenun khas Bima yang telah dihasilkan, antara lain:

1. Kain tenun khas Bima dengan berbagai bentuk motif dan jenis bahan yang digunakan.

2. Kain tenun khas Bima dengan perpaduan bentuk dan jenis motif yang dihiasi warna pada nilai-nilai simbol tenun khas Bima.

3. Kain tenun khas Bima dengan makna simbol, motif dan bahan tradisional.

Dahulu motif-motif ini dikaitkan dengan aspek keagamaan, upacara adat, seperti dalam ritual kelahiran anak, perkawinan, dan kematian. Selain itu, dalam kehidupan masyarakat, jenis kain serta warna dan bentuk motif kain tertentu dipakai oleh lapisan masyarakat tentu pula atau memegang peranan di daerah tersebut.

Dalam perkembangannya, bentuk motif dan kain tenun tidak hanya digunakan busana atau pelengkapan upacara adat. Namun juga digunakan sebagai penunjang interior di dalam kehidupan masyarakat Bima dalam melestarikan atau melakukan upacara adatnya (I. Singke, MR. Pahlevi putra N, 2011: 17-18).

\section{B. METODE PENELITIAN}

Pendekatan yang digunakan dalam penelitian ini adalah pendekatan kualitatif deskriptif. Untuk melakukan sebuah penelitian ilmiah yang mengkaji fenomena dan gejala di sekitar kita.

Adapun penelitian kualitatif menurut Kairk dan Miller (1986) kualitatif adalah merupakan kata-kata tertulis/lisan dari orang-orang yang prilakunya diamati dan berupa tradisi tertentu dalam ilmu pengetahuan sosial yang secara fundamental bergantung dari pengamatan pada manusia baik dalam kawasannya maupun dalam peristilahannya, (dalam Moleong, 2007: 4).

\section{HASIL DAN PEMBAHASAN}

\section{Makna Simbol dan Motif Kain Tenun Khas Masyarakat Bima}

Perkembangan makna simbol dan motif kain tenun khas masyarakat Bima semakin meningkat dari tenun benang yang dibuat secara alami dan dihiasi dengan macam-macam bentuk motif dalam makna simbol yang tradisional sampai pada penggunaan bahan dasar modern. Ini telah menunjukan bahwa motif, karya seni kain tenun khas Bima mulai berkembang maju dan tidak tertutup pada kemajuan teknologi modern dan masyarakat Bima tidak kalah dengan kemajuan zaman modern.

“Berdasarkan hasil wawancara dengan Ibu Halima ketua kelompok CV. Mekar Sari Raba Dompu mengatakan bahwa awalnya tenun khas Bima hanya dikerjakan oleh ibu-ibu dan remaja tetapi dirumah masing-masing dan untuk dipakai sendiri. Lama kelamaan seiring dengan perkembangan zaman mereka sudah mulai berpikir dalam membentuk sebuah makna simbol dan motif dengan cara menenun untuk mengembangkan usaha tenun mereka agar lebih menghasilkan dan memperluas konsumennya. Sarung yang mereka hasilkan adalah songket motif istana Bima, "Tembe salungka", tembe songket dan tembe nggoli serta tembe (sarung) dan bentuk-bentuk lainnya sesuai dengan pesanan dan kebutuhan. (Wawancara pada tanggal, 18 Mei 2015)".

\section{Proses Pembuatan Motif Kain Tenun Khas Bima}

Proses pembuatan motif kain tenun khas Bima hampir sama dengan proses pembuatan dan kegiatan tenun pada daerah lain. Tetapi tentu Bima mempunyai ciri 
khas sendiri sehingga hasil motif kain tenun berbeda dengan hasil motif tenun daerah lain dan menunjukan bahwa Bima juga mampu melahirkan kreasi dan kreatifitas yang unik dan menarik serta bernilai jual tinggi. Proses pembentukan motif serta nilai simbol yang dihiasi pada tenun tersebut adalah sebagai berikut:

a. Pemilihan benang yang dibutuhkan untuk menenun

b. "Moro Kafa" yaitu penggulungan benang untuk mempermudah proses menenun.

c. "Ngana" yaitu proses pembentalan benang dan penentuan.

d. "Kili Bunga" proses menentukan motif yang akan digunakan saat menenun.

e. Benang dilipat pada tempat dan dilengkapi dengan alata-alat yang dibutuhkan.

f. Sesudah di siapkan kebutuhan dalam menenun, maka dilangsungkan untuk melaksanakan kegiatan menenun, (Wawancara dengan Ibu Rosdiana Tanggal, 21 Juni 2015).

3. Perkembangan Bentuk-Bentuk motif atau Simbol Kain Tenun khas Daerah Bima

Masyarakat Mbojo (Bima), Kain Tenun khas Bima terus mengalami perkembangan, motifnya yang terus beragam menjadikan suatu bahan busana yang berkelas, makna simbol yang manfaat dalam bentuk kepercayaan apa lagi didukung oleh makna gambar serta bahan busana modern, di dalam kegiatan tenun tentu memiliki lazin dalam artian yaitu makna simbol dalam menentukan ragam hias yang dijadiakan motif, Hal ini seperti yang dinyatakan oleh Ibu. Jaenab, Menurutnya adalah:

"Motif (ragam hias) kain disebut juga "salungka bagi penenun di Raba Dompu. Artinya sebuah pola yang mengisi bagian-bagian dari kain. Misalnya, salungka tertentu di pilih untuk badan kain salungka lain untuk kepala kain dan beberapa makna motif yang lazim digunakan untuk membatasi antara beberapa bentuk motif. Sedangkan kalau disebut motif salungka pa'a yang dimaksud adalah corak keseluruhan kain yang dihiasi dengan motif". (wawancara pada hari Jum'at pada tanggal 23 Juni 2015)

Adapun pernyataan yang lebih terinci seperti pertanyaan yang dilontarkan oleh pewawancara kepada Ibu. Fatimah salah seorang anggota CV. Mekar sari Kelurahan Raba Dompu di lingkungan Raba ketika peneliti temui pada tanggal 23 Juni 2015. Ibu Fatimah menyatakan bahwa:
"Sarung", sambolo (Destar) dan Weri (ikat pinggang tradisional) merupakan hasil kerajinanyang berbagai bentuk motif serta makna simbol dalam ragam hias yang laris dalam perdagangan nusantara. Para pedagang nusantara terpikat pada hasil tenun khas Mbojo (Bima), bukan hanya karena mutunya tetapi memilki motif khas yang berbeda dengan motif tenun suku lain dan mempunyai makna dalam kehidupan".

\section{Ragam Hias Motif Tenun Khas Daerah Bima}

Dalam memilih simbol dan gambar untuk dijadikan ragam hias tenun, para penenun harus berpedoman pada nilai dan norma adat islami. "Sebagai gambaran jati diri atau kepribadian Dou Mbojo (Orang Bima) yang taat pada ajaran agamanya tenun khas Bima tidak kalah dengan tenun daerah lain yang terkenal seperti Bali, NTT, Jawa, Sumatra maupun Sulawesi. Karena tenun khas Bima mempunyai ciri-ciri khusus dan unik yang membedakannya dengan tenun khas daerah lain. Sejalan yang di nyatakan oleh Ibu. Sulaimah saat diwawancarai pada tanggal 27 Juni 2015 bahwa:

"Jenis makna simbol tenun khas daerah Bimapun beragam mulai dari tenun songket, salungka, masrai, nggoli, pa'a, bali, dan jenis-jenis lainnya. Jenis tersebut juga mempengaruhi keragaman motif yang tercipta mulai dari motif bunga, daun, garis-garis motif kotak-kotak, tumbuhan, motif bunga samobo yang biasa ada di sawah, bungasatako, model burung, dan tulisan-tulisan nama sesuai pesanan pelanggan".

Tenun Bima juga menggunakan tenun bersambung sebuah model yang mengingatkan kita pada kain kembang Jogja maupun Sumatra dan beberapa jenis dibawah ini.

a. Tembe kafa na'e (Sarung dari benang besar). Sarung dari benang besar dalam pengertian, sarung yang ditenun dari benang asli dibuat oleh para penenun dengan bentuk motif yang unik dan sangat inda.

b. Tembe bali mpida (Sarung bali kecil)Bermotif garisgaris kecil, yang akan membentuk kotak-kotak yang segi empat ukuran kecil.

c. Tembe bali lomba Sarung yang motifnya berupa garisgaris lurus yang besar dan akan membentuk kotakkotak besar pula (Wawancara, Ibu. Hadijah pada tanggal 27 Juni 2015). 


\section{Pengembangan Tenun Khas Bima}

Tenun khas Bima tidak tertutup untuk menerima model dan perkembangan pada tenun daerah-daerah lain. "Tidak berarti Bima mengadopsi tanpa merubah sedikitpun dari model atau motif yang di ambil. Tetapi model dan motif tenun daerah lain hanya dijadikan salah satu masukan dalam kegiatan ini, sehingga melahirkan karya baru dengan tidak menghilangkan ciri khas Bima "Muna" (Tenun) itu sendiri". Dalam kegiatan atau dari karya tersebut yang dituturkan oleh Ibu Misna sebagai berikut :

\section{a. Tenun Bima Yang Bermotif Hiasan Dinding (Ciri khas)}

Tenun khas Bima Dapat juga dihias dengan sulaman, tulisan dan hiasan tambahan lain seperti benang warna dan kain metalik atau pita untuk pengantara jarak lebar dari geometris Yang dijadikan motif dan desain tumbuhan seperti corak desain bali dan india (Buhler dan ficher 1979: 159) berpendapat bahwa pola awal disebut "patola" misalnya merupakan salah satu terpopuler dari seluruh kain impor dari india ke Asia Tenggara, seperti pernyataan Ibu Juraidah bahwa:

"Penenun Bima menghasilkan "Nggusu Waru" (Segi delapa), dan bunga "kakando" (Tunas bambu) juga telah di pengaruhi oleh "patola" yaitu salah satu motif yang sangat populer dan makna ragam hias pada kain tenun daerah Bima".

\section{b. Desain Motif Tenun Khas Bima}

Peluang ekspor kain tenun tradisional sangat terbuka, "terutama bila dibentuk menjadi perlengkapan rumah tangga dan aksesoris, deemikian agar ragam motifnya semakin diperlukan sentuhan para ahli dekorasi dan desainer untuk merancang busana, perlengkapan, ornament dari bahan tersebut", Hasil wawancara pada tanggal 28 Juni 2015 . Dan pernyataan Ibu Sukinah bahwa:

"Di Bima pun untuk menarik perhatian masyarakat dan menambah ketertarikan masyarakat terhadap tenun khas Bima yang bermacam bentuk motif, maka dibuat desain khusus berupa baju, selendang, rok yang kemudian diperkenalkan melalui fashion show maupun pameran-pameran kecil atau seragam kantor, pesta dan sebagainya".

\section{SIMPULAN DAN SARAN}

Berdasarkan hasil penelitian diatas dapat di simpulkan bahwa:

1. Kain tenun khas daerah Bima bermakna dalam menentukan simbol dan masih sederhana yaitu dalam membentuk sebuah ragam hias yang dijadikan motif dan keunikan motif yang berpatokan pada kepercayaannya masyarakat daerah Bima.

2. Kain tenun khas daerah Bima juga bernilai tinggi dalam menentukan bentuk ragam motif, serta nilai kerajinan tenun inipun berkembang pesat baik dalam makna simbol maupun kualitas ragam hias atau khusus kain tenun masyarakat daerah Bima pada umumnya.

3. Dari beberap makna simbol (Motif) yang dibuat pada kain tenun khas daerah Bima adalah ada yang berbentuk daun, burung, ayam, kakando (Rebung), daun bunga, bunga satako, kotak-kotak, garis-garis yang mengandung arti tersendiri dalam segi kualiatas kepercayaan masyarakat daerah Bima.

\section{DAFTAR RUJUKAN}

ABD. Wahab H. I, (1982). Tenun Tradisional Nusa Tenggara Barat. Proyek Pengembangan Permuseuman NTB.

H. Umar H. Abu Bakar Husain, BA, (2006). Tenunan dan Wanita Bima. Kantor Pemberdayaan Masyarakat dan Perempuan Kota Bima.

http://www. google. Pakaian hasil tenun Bima. Com. Di akses Tanggal 25 Juli, pukul 09: 00 Malam Wita

I. Latif, (2012). Busana Tenunan Nusantara. PT. Intan Sejati Kelaten.

Juli S. Komalasari, (2011). Ragam Corak Tenun Ikat NTB. Jl. Raya Sukarara, Lombok Tengah.

Kurniawan, Doni, (2010). Kamus Praktis Ilmiah Populer. Balai Pustaka, Surabaya.

Malingi, Alan, (2010). Mengenal Alat Tenun Bima Dompu, Kekalik Mataram.

Malingi Alan, (2010). Ragam Pakaian Adat Bima Dompu, CV. Mahami Persada, Jl. Meninting Raya 47

Kekalik Matara

M. Hilir Ismail, Siti Linda Yuliarti, (2007), Rahma fitriah, Seni Budaya Mbojo, Bima.

Muhlis, S. Ag, (2011). Permata Kearifan dari Naskah Kuno Kesultanan 